\title{
Influence of Ocean Topography on Tsunami Propagation in Western Australia
}

\author{
Charitha Pattiaratchi \\ Oceans Graduate School and the UWA Oceans Institute, The University of Western Australia, 35 Stirling \\ Highway, Perth WA 6009, Australia; chari.pattiaratchi@uwa.edu.au; Tel.: +618-6488-3179
}

Received: 10 July 2020; Accepted: 14 August 2020; Published: 19 August 2020

\begin{abstract}
Western Australia is susceptible to tsunamis from seismic sources that originate from distant sources including the Sunda Arc. Many surface and subsurface topographic ocean features are located between the Australian continent and locations where tsunamigenic earthquakes occur. These include the Venin Meinesz Seamounts (including Christmas Island) and Horizon Ridge, Exmouth, Zenith and Cuvier Plateaus. Numerical simulations of idealised tsunamigenic earthquakes along the Sunda Arc revealed that these topographic features have a large influence on the distribution of tsunami heights, propagating speeds and energy distribution. The interaction between tsunami waves and Venin Meinesz Seamounts and Horizon Ridge, located close to the earthquake locations, scatter the tsunami energy into several beams. Exmouth Plateau acts as a focusing feature to increase wave heights between North West Cape and Barrow Island whilst Cuvier Plateau deflects energy towards Shark Bay. Although Zenith Plateau has a local effect, it does not influence tsunami waves along the coast. Southwest Australia is "sheltered" from the direct effect of tsunami waves from Sunda Arc due to the combined effects of the Seamounts and Cuvier Plateau in the scattering and refraction of tsunami waves.
\end{abstract}

Keywords: tsunami; numerical simulation; offshore topography; Western Australia

\section{Introduction}

Devastation (loss of lives and coastal infrastructure) due to tsunami impacts along coastal regions have been highlighted by recent mega-tsunamis in the Indian and Pacific Oceans. The region has also been impacted by tsunamis over the past two to three centuries (Figure 1; [1]). The Indian Ocean tsunami ("Boxing Day" tsunami) revealed the destructive effects of tsunamis across the Indian Ocean with a maximum run-up exceeding $30 \mathrm{~m}$ in Banda Aceh (Indonesia) [2]. In Western Australia, the impact was greatly reduced with a maximum total water level of $2.6 \mathrm{~m}$ recorded at Geraldton (Figure 2). The December 2004 tsunami was followed by much smaller basin-wide tsunamis in 2005, 2006 and 2007 [2]. Although these tsunamis caused a loss of lives and damage to property in the immediate vicinity of the tsunami generation region in Indonesia, regions located far from the earthquake epicentre (e.g., Western Australia) did not experience the tsunami's damaging impacts; however, local sea level recording stations documented the characteristics of each tsunami [2]. 


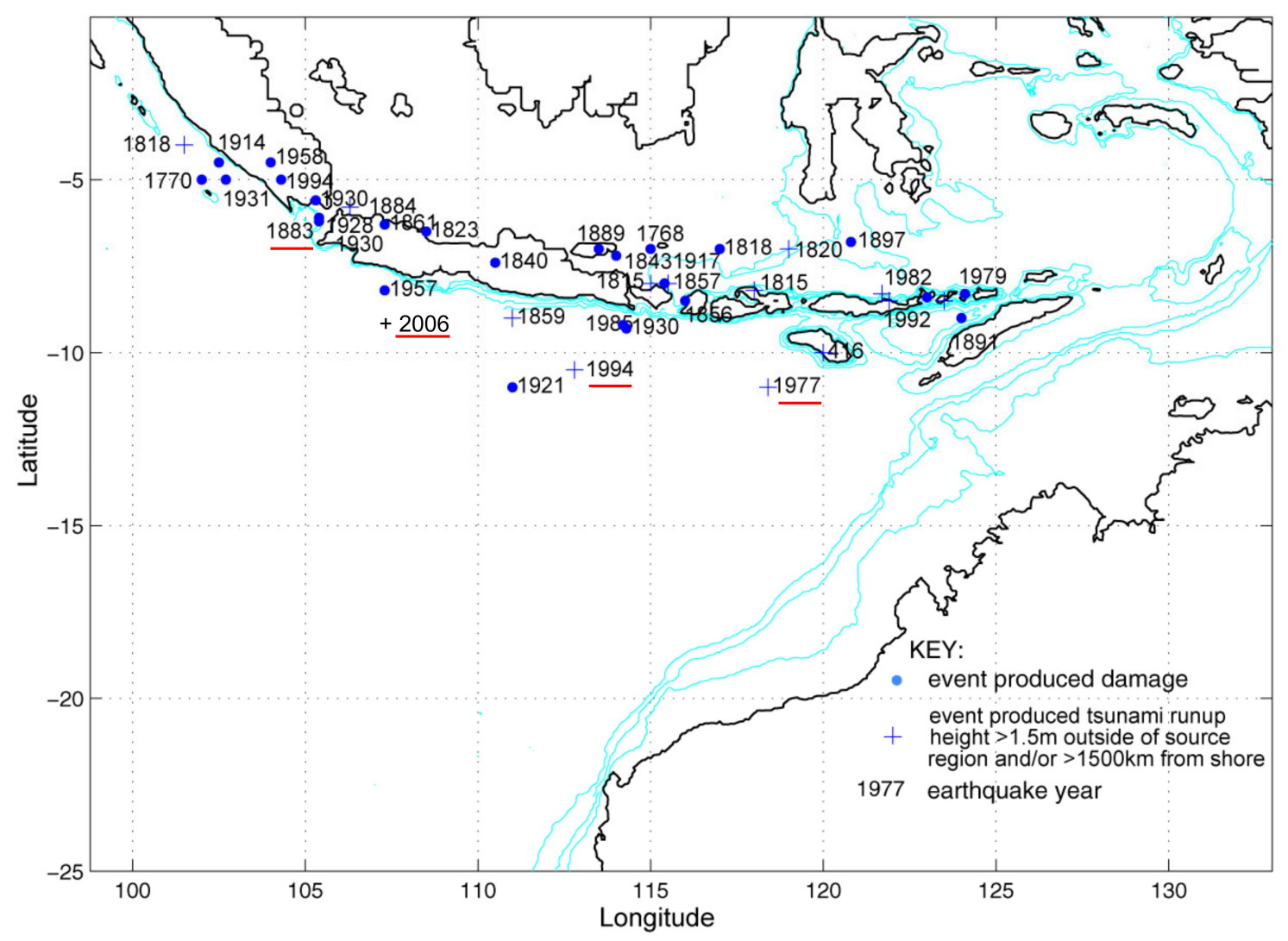

Figure 1. Location of earthquakes generating tsunami in the northwest of Australia (from Pattiaratchi and Woo [1]). The red underlined events created a tsunami that was recorded in Australia.

A tsunami is a wave train consisting of a series of waves of long wavelength $(>100 \mathrm{~km})$ and period (order of hours) generated in a body of water by an impulsive disturbance, which vertically displaces the water. Tsunamis are primarily associated with earthquakes in oceanic and coastal regions. Landslides, volcanic eruptions, nuclear explosions and even impacts of objects from outer space (such as meteorites, asteroids and comets) can also generate tsunamis. Tsunamis may also be generated through atmospheric disturbances that are known as meteorological or meteotsunamis [3,4]. Globally, the most common tsunamis are those associated with tectonic earthquakes associated with the earth's crustal deformation. Although, there are regions, including southwest Australia, where meteotsunamis are a common occurrence [3,4]. An earthquake that produces a tsunami is known as a tsunamigenic earthquake. When a tsunamigenic earthquake occurs beneath the sea, the water above the deformed area is displaced from its equilibrium position. Waves are formed as the displaced water mass, which acts under the influence of gravity, attempts to regain its equilibrium. This displacement of the sea surface initiates a series of waves radiating outwards from the initial disturbance. When large areas of the seafloor elevate or subside, a tsunami can be created. The main factor that determines the initial size of a tsunami is the degree of vertical seafloor deformation that is controlled by the earthquake's magnitude, focal depth (the depth below the seabed at which the earthquake occurs), fault characteristics and coincident slumping of sediments or secondary faulting. Generally, for a tsunami to be generated, the earthquake should have a moment magnitude $(\mathrm{Mw})>6.5$ to be relatively shallow-between 20 and $100 \mathrm{~km}$ below the seafloor. A shallower depth provides the strongest "impulse" but a deeper earthquake distributes the "impulse" over a larger area [5]. 


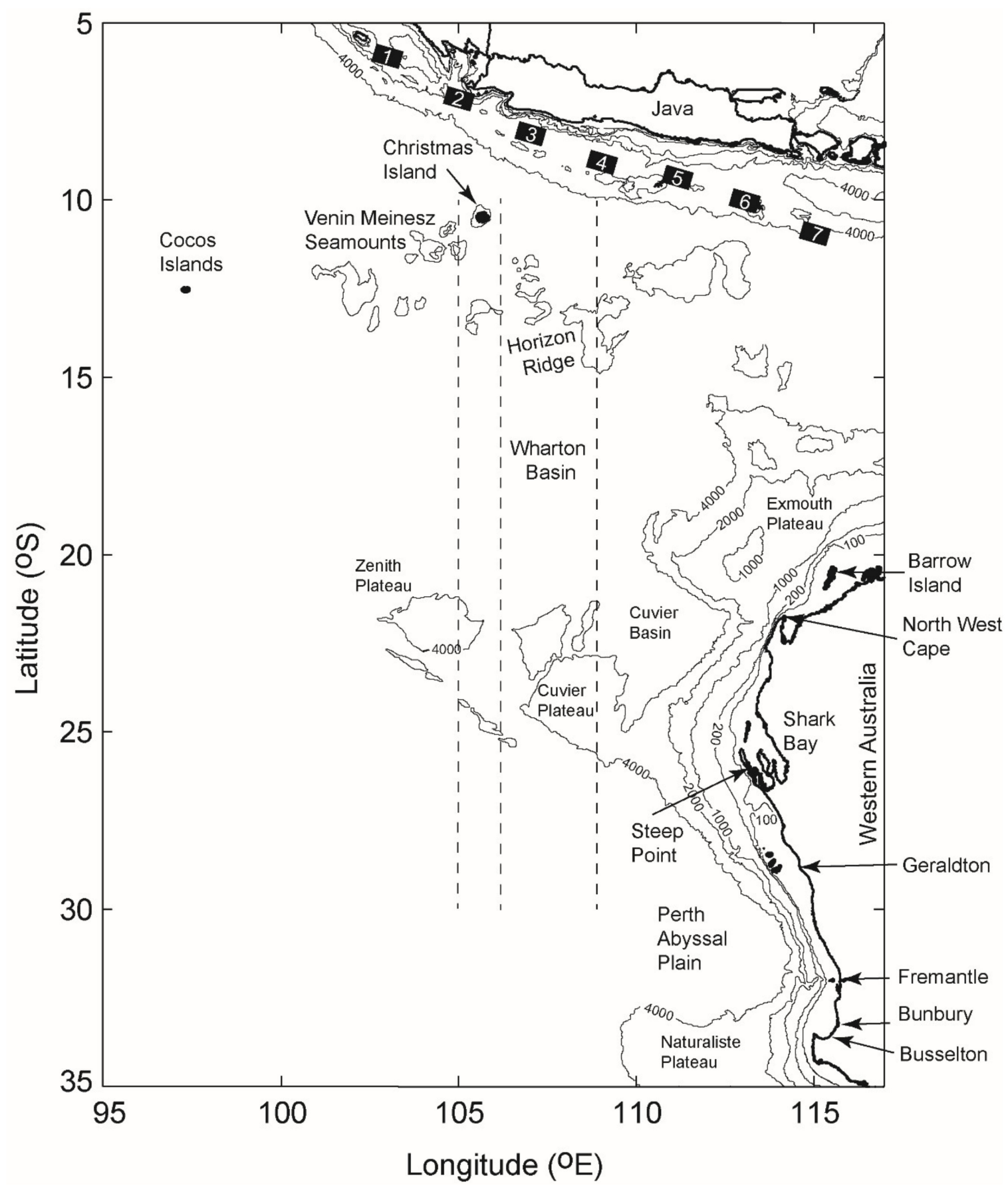

Figure 2. Location of the study region showing the locations mentioned in the text. Bathymetry is in meters. The locations of the simulated tsunamigenic earthquakes are also shown as numbered black boxes. The vertical dashed lines at $105^{\circ} \mathrm{E}, 106.5^{\circ} \mathrm{E}$ and $109^{\circ} \mathrm{E}$ represent cross-sections along where water levels were extracted.

Tsunamis are classified as shallow-water waves where the wavelength is larger compared to the water depth. As the tsunami crosses the deep ocean, its wavelength from crest to crest may be several hundred kilometres or more, and its height from crest to trough will be only $<1 \mathrm{~m}$. The celerity (c, speed) of the tsunami controlled only by water depth (h): $c=\sqrt{g h} ; g$ is the acceleration due to gravity. Thus, as the water depth decreases, the speed of the tsunami also diminishes. The energy flux of the tsunami, which is dependent on its wave celerity and wave height, remains nearly constant. Therefore, as the tsunami speed decreases as it enters shallower water, the height of the wave grows. 
The tsunami waves extend through the whole water column even in the deep ocean where water depths are $>5000 \mathrm{~m}$. Changes in bottom topography due to underwater plateaus, mid-ocean ridges and seamounts have a significant effect on tsunami propagation. For example, a decrease in water depth from 5000 to $2000 \mathrm{~m}$ will decrease the celerity of the wave from 220 to $140 \mathrm{~ms}^{-1}$, a decrease of $37 \%$. Changes in wave celerity also result in wave refraction that will change the direction of wave propagation.

For Australia in general, the historical threat of tsunamis from seismic sources originates from distant sources [6,7]. Tsunamis in the Indian Ocean are rare, with $\sim 24$ tsunamis reported over a 2000-year period prior to 2004 [8]. Western Australia (WA) is susceptible to the action of tsunamis generated by earthquakes in the Sunda Arc region (Figure 1). Although there have been many earthquakes in the region, only seven earthquakes have resulted in tsunamis which have been observed (either through visual records or tide gages) in Australia. Evidence of mega-tsunamis affecting Barrow Island and Shark Bay (Figure 2) some 2500 to 5500 years ago have been reported [9]. A feature of the tsunamigenic earthquakes affecting WA is that either they have been located immediately to Australia's northern coastline (e.g., earthquakes in 1977 and 1994, Figure 1) or have been large events recorded throughout the Indian Ocean (e.g., in 1883, 2004, 2005, 2006 and 2007 [2]). The maximum run-up height of $7.9 \mathrm{~m}$ was recorded at Steep Point (Figure 2) during the Pangandaran earthquake and tsunami that occurred on 17 July 2006. This is considered as the largest tsunami run-up recorded in mainland Australia [10]. However, the wave heights recorded in southwest Australia, south of Geraldton due to seismic tsunamis are relatively small. For example, at Fremantle, the maximum wave height recorded during the 2004 Indian Ocean tsunami was $0.6 \mathrm{~m}$ that is frequently exceeded by meteorological tsunamis on an annual basis [3]. In addition, the maximum tsunami waves that were recorded at the two southern stations (Bunbury and Busselton) were postulated to be waves reflected from the Mascarene Plateau as these waves were recorded more than $15 \mathrm{~h}$ after the earthquake and $10 \mathrm{~h}$ after the arrival of the initial wave [2].

It has been documented that ocean topography plays a major role in tsunami wave propagation through wave refraction changing the wave directions in deep water before affecting particular sections of the coastline $[11,12]$. There are a number of bathymetric features between the Sunda Trench where tsunamigenic earthquakes occur and the Australian mainland (Figure 2) and thus provide an ideal ocean basin to examine the ocean topography on tsunami propagation. The aim of this paper is to use numerical simulations of tsunami propagation, using idealized tsunamigenic earthquakes, to examine the role of these bathymetric features on tsunami impacts along the West Australian coastline.

\section{Study Region}

The aim of this study is to examine the role of surface and subsurface ocean topography that influence the propagation of tsunami waves to southwest Australia. In particular, the region between Geraldton and Busselton (Figure 2) where $>90 \%$ of the West Australian (WA) population live is the focus. Studies have shown that in comparison to other regions of Australia, the WA coastline experiences a relatively high frequency of tsunami occurrence through the tsunamigenic earthquakes along the Sunda Arc, south of Indonesia [7,12]. Large tsunamigenic earthquakes offshore of Java and Sumba are likely to be a greater threat to WA than those offshore of Sumatra or elsewhere in Indonesia [7,12]. Many topographic features are located between the Sunda Arc and southwest Australia that could influence tsunami wave propagation and include (Figure 2): Christmas Island, Venin Meinesz Seamounts, Horizon Ridge and several plateaus (Zenith, Cuvier, Exmouth).

The abyssal plain in the northern section of Wharton Basin (Figure 2) lies at 5000 to $6000 \mathrm{~m}$ and is cut by volcanic seamounts and ridges that include the Venin Meinesz Seamounts and the Horizon ridge [13]. Venin Meinesz Seamounts is a chain of seamounts trending broadly east to west along latitude $12^{\circ} \mathrm{S}$ that are located in a volcanic province [14]. It covers an area of $\sim 1,000,000 \mathrm{~km}^{2}$ and comprises the Vening Meinesz chain, Cocos and Christmas Rises and numerous unnamed large and small volcanic cones formed on eroded guyot platforms and frequent uneroded seamounts [15]. In this 
region, the seafloor is at $\sim 5500$ water depth with the large seamounts rising up to $3000 \mathrm{~m}$ from the seafloor and the morphology of the seamounts indicating their volcanic origin with very steep slopes and almost circular conical shapes [16]. Here, the seamount summits are frequently above $2000 \mathrm{~m}$ below sea level, usually being 40 to $50 \mathrm{~km}$ in diameter [16].

An expansive bathymetric high is located to the south of Wharton Basin and offshore Shark Bay extending $1000 \mathrm{~km}$ offshore in an NW direction and includes the Cuvier Plateau (also known as Wallaby Plateau) and the Zenith Plateau (Figure 2). The bathymetric high is bordered to the north by the Cuvier Abyssal Plain and in the south by the Perth Abyssal Plain. The Cuvier Plateau lies in water depths of $5000 \mathrm{~m}$ rising to $2200 \mathrm{~m}$ at the shallowest region and covers an area of $\sim 100,000 \mathrm{~km}^{2}$ (Figure 2). The Zenith Plateau is separated from the Cuvier Plateau by a 100 to $150 \mathrm{~km}$ wide bathymetric trough. The shallowest region of the Zenith Plateau lies $1960 \mathrm{~m}$ below sea level with its base at $\sim 5000 \mathrm{~m}$ water depth. It is $\sim 300 \mathrm{~km}$ long and $\sim 200 \mathrm{~km}$ wide.

\section{Methodology}

For this study, the MOST (Method of Splitting Tsunami) model [17-20] was used. MOST is a suite of numerical simulation codes capable of simulating three processes of tsunami evolution: earthquake, transoceanic propagation and inundation of dry land. As the aim of this paper is to examine the role of offshore topography on tsunami wave propagation, the inundation of dry land was not implemented. The tsunami generation model assumes a fault plane model of the earthquake source based on an elastic half-space overlaid with an incompressible liquid layer representing the earth's crust and ocean, respectively [20]. Linear models are used to study the generation process of the model because the gravity wave formation due to the initial water disturbance is generally a slow process driven by hydrostatic forces with negligible non-linear effects [21]. The propagation algorithm of the model is extremely flexible and can simulate tsunami movement over basin scales. The MOST model has been validated and verified substantially through analytical solutions, experimental results and field measurements as outlined in Synolakis et al. [22,23]. The MOST model is implemented in the ComMIT model [24] but in this study, the original code was used.

The MOST model was run on the Pawsey Centre supercomputing facilities. The model domain is shown in Figure 1 and consisted of an 1801 (latitude) and 1021 (longitude) grid at 60-arc-second $(\sim 1.852 \mathrm{~km}$ or $1 \mathrm{~nm})$ resolution. Bathymetry was sourced through the GEBCO database. Seven different tsunamigenic earthquake locations were defined along the Sunda Arc (Table 1; Figure 2). Characteristics of each tsunamigenic earthquake were identical with each having a moment magnitude of 8.2 with both the focal depth and slip being $10 \mathrm{~m}$ (Table 2). The model time step was $5 \mathrm{~s}$ and each scenario was simulated over a period of $360 \mathrm{~min}(6 \mathrm{~h})$ and took several hours to complete even on a supercomputer. The simulation period ensured that the tsunami waves had propagated through the entire domain and exited the southern boundary. The model output was used to create a series of snapshots of water levels both as spatial differences and as time series, as well as the maximum wave heights for each scenario.

Table 1. Location of the tsunamigenic earthquakes offshore of Java used for the simulations.

\begin{tabular}{cccccccc}
\hline & $\mathbf{1}$ & $\mathbf{2}$ & $\mathbf{3}$ & $\mathbf{4}$ & $\mathbf{5}$ & $\mathbf{6}$ & $\mathbf{7}$ \\
\hline Latitude $\left({ }^{\circ} \mathrm{S}\right)$ & 6 & 7 & 8 & 9 & 9 & 10 & 11 \\
\hline Longitude $\left({ }^{\circ} \mathrm{E}\right)$ & 103 & 105 & 107 & 109 & 111 & 113 & 115 \\
\hline
\end{tabular}


Table 2. Characteristics of the tsunamigenic earthquakes used for the simulations.

\begin{tabular}{ll}
\hline Length $(\mathrm{km})$ & 100 \\
\hline Width $(\mathrm{km})$ & 50 \\
\hline Dip $\left(^{\circ}\right)$ & 25 \\
\hline Rake $\left(^{\circ}\right)$ & 90 \\
\hline Strike $\left(^{\circ}\right)$ & 300 \\
\hline Slip $(\mathrm{m})$ & 10 \\
\hline Depth $(\mathrm{km})$ & 10 \\
\hline Moment magnitude & 8.2 \\
\hline
\end{tabular}

In the linear shallow water wave theory, wave energy is proportional to the square of the wave height. Therefore, the distribution of maximum wave heights over the model domain provides a useful indication of the characteristics of tsunami propagation. These maps, termed "energy maps" represent the maximum wave heights the open ocean caused by the tsunami and indicate that the kinetic energy of the tsunami was not distributed evenly across oceans but instead form directional "beams" where tsunami wave energy is concentrated. Energy maps for each of the tsunamigenic earthquake scenarios were constructed to identify the directional beams due to the offshore topographic features.

\section{Results}

\subsection{Time Series}

The time series of tsunami wave propagation from the tsunamigenic earthquake scenario four highlights the influence of ocean topography (Figure 3). Twenty minutes after the earthquake the leading crest of the tsunami wave was symmetric and approaching the Venin Meinesz Seamounts (Figure 3a). After $40 \mathrm{~min}$, the leading crest of the tsunami wave had passed Christmas Island, Venin Meinesz Seamounts and the Horizon Ridge and had made landfall in Java (Figure 3b). At 60 min, the leading waves had progressed to the Wharton Basin with many local oscillations present in the region of seamounts (Figure 3c). Over the period of 80 to $120 \mathrm{~min}$, the wave transited across Wharton Basin and approached the three main plateaus (Figure 2): Zenith, Cuvier and Exmouth (Figure 3d-f). The Exmouth Plateau slowed the propagation due to reduced depth (Figure 3f). The interaction between the tsunami waves with Zenith and Cuvier Plateaus occurred between 100 and $120 \mathrm{~min}$ with the propagation speed of the wave crest decreasing over the summits of the plateau. This was noticeable as the wave propagated over the deeper water between the Zenith and Cuvier Plateaus; the wave crest is advanced to the south compared to that over the plateaus (Figure 3f). At $140 \mathrm{~min}$, the tsunami waves had made landfall at North West Cape (Figure 2) on the Australian mainland (Figure 3g). Along $25^{\circ} \mathrm{S}$, the single tsunami wave crest had decomposed to three separate crests downstream of the plateaus (c.f. Figure $3 \mathrm{~d}, \mathrm{~g}$ ) and secondary wave crests were visible downstream of the plateaus (Figure $3 \mathrm{~g}$ ). Over the subsequent $40 \mathrm{~min}$, the waves propagated southward but with two clear leading wave crests (Figure $3 \mathrm{~h}, \mathrm{i}$ ). 

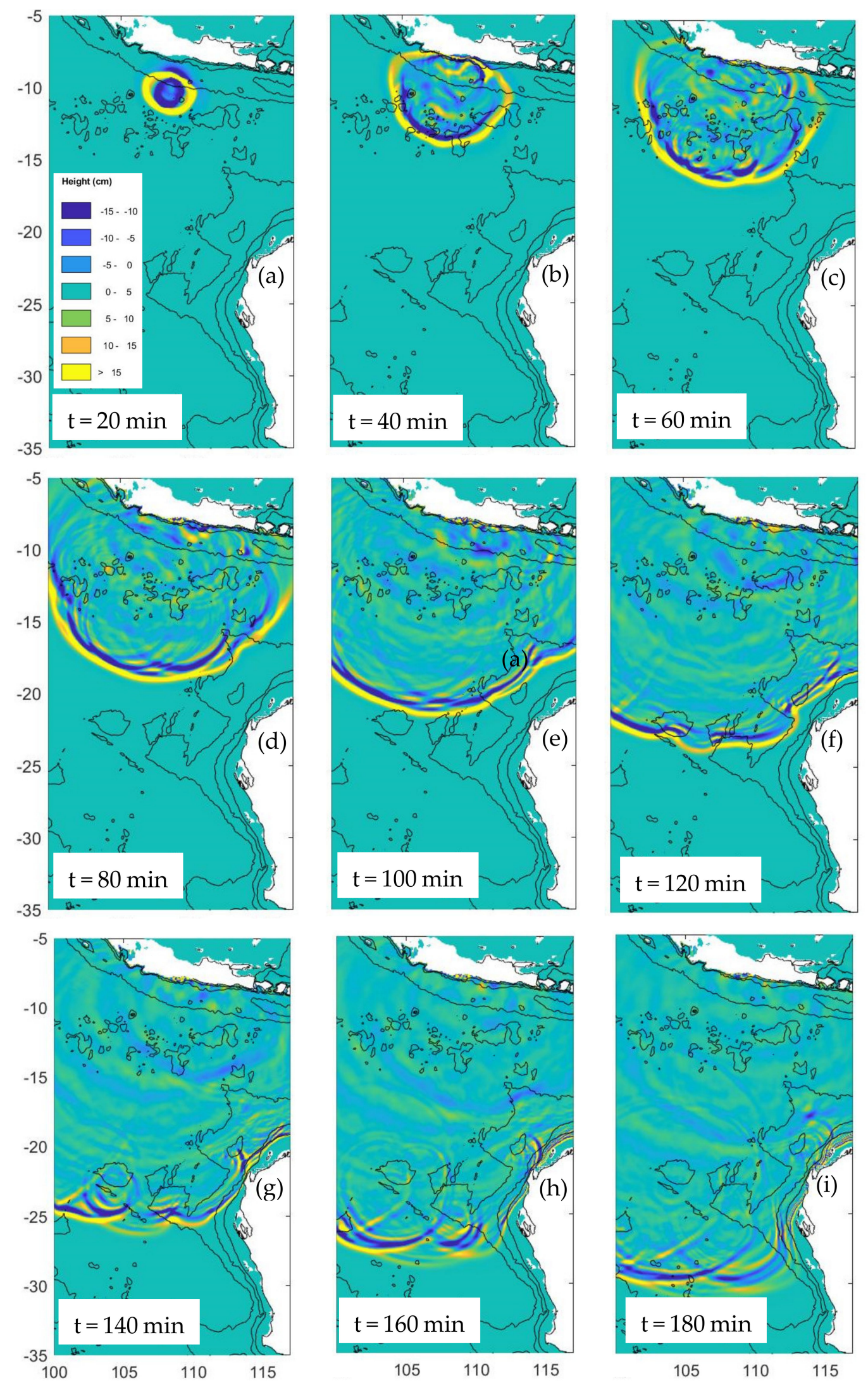

Figure 3. (a-i): Snapshots of tsunami wave propagation from tsunamigenic earthquake scenario 4 . Yellow and blue colours represent positive and negative water levels, respectively. The elapsed time from the occurrence of the earthquake is shown. The 200, 1000 and $4000 \mathrm{~m}$ depth contours are shown. 
The propagation of the tsunami waves indicated a general decrease in wave height with distance travelled (Figure 4). Initially, the maximum wave heights were $\sim 100 \mathrm{~cm}$ at $\sim 12^{\circ} \mathrm{S}$ (along $109^{\circ} \mathrm{E}$ ) prior to interaction with the topography. There was a slight decrease in wave heights $(80$ to $90 \mathrm{~cm})$ when the waves arrived at Wharton Basin and further decreased $(40$ to $70 \mathrm{~cm})$ when approaching the plateaus (Figure $4 \mathrm{~b}$ ). There was a significant reduction in the wave heights as the tsunami crossed the plateaus: there was a reduction of $60 \%$ and $48 \%$ in wave height as the waves passed over the Zenith and Cuvier Plateaus (red and black lines), respectively. There was only a $15 \%$ reduction in wave heights as they crossed the bathymetric trough between the two plateaus (Figure $4 \mathrm{~b}$ ).

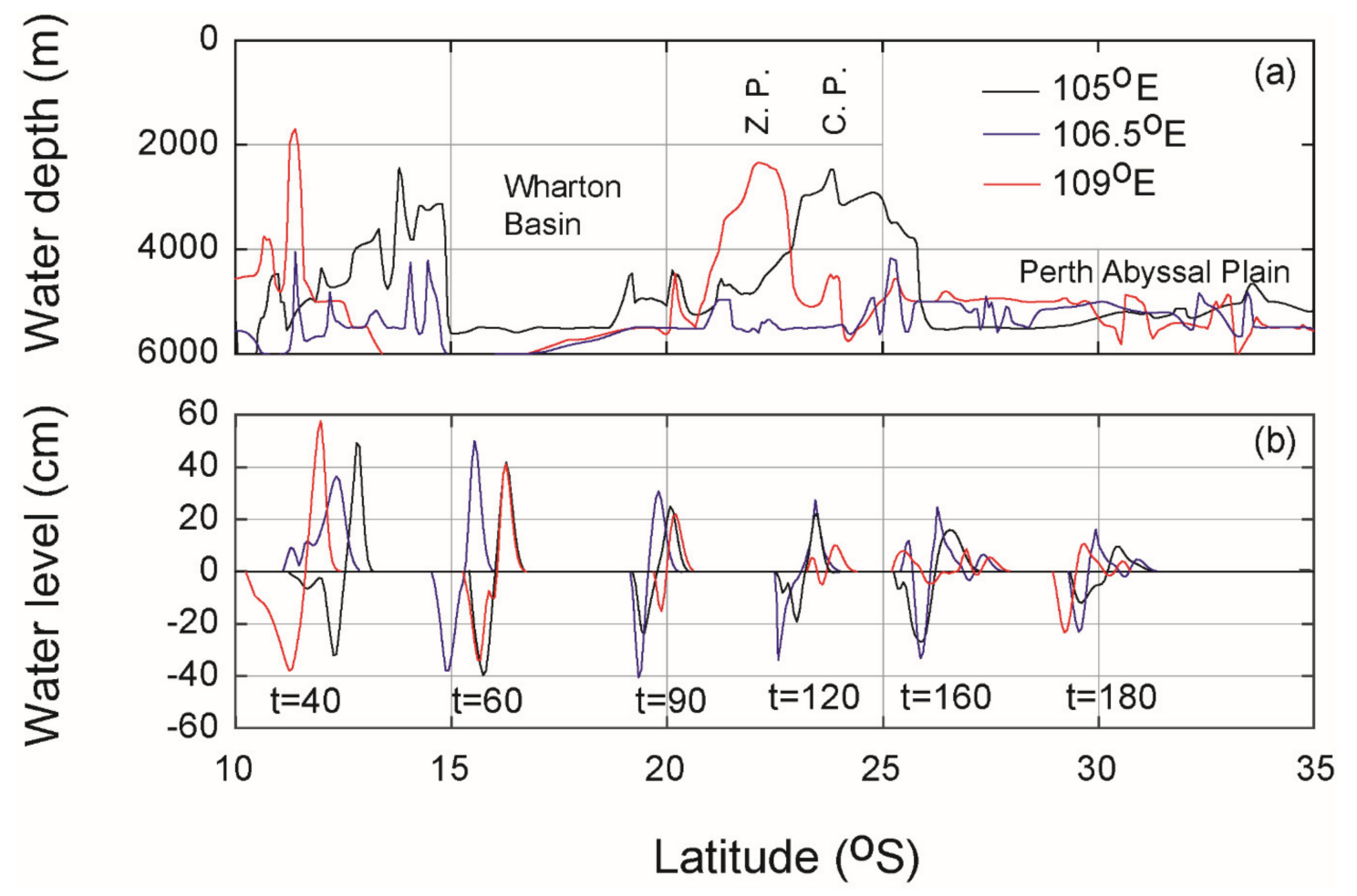

Figure 4. (a) Bathymetry cross-sections in the north-south direction at $105^{\circ} \mathrm{E}, 106.5^{\circ} \mathrm{E}$ and $109^{\circ} \mathrm{E}$ representing sections across Zenith Plateau (red lines), bathymetric trough (blue lines) and Cuvier Plateau (black lines), respectively; (b) leading tsunami wave profiles from tsunamigenic earthquake scenario 4 at different elapsed time (in minutes) after the earthquake. The locations of the cross-sections are shown in Figure 2. Note that only the leading waves of the tsunami are shown.

The time series of surface elevation along the $100 \mathrm{~m}$ contour offshore at five different locations along the coastline was extracted from the model output for the tsunamigenic earthquake 4 scenario. This is the centre point of the seven scenarios and was located close to the 2006 tsunami (Figures 1 and 2). Note that for scenarios located to the east $(6,7)$, the Australian continental landmass acts as a shelter to locations south of Shark Bay (Figure 2). The results for scenario 4 indicated significant spatial changes in the tsunami wave heights along the coast (Figure 5). Maximum wave heights $(>210 \mathrm{~cm})$ were predicted at North West Cape due to the proximity of the location to the earthquake source and due to focusing from Exmouth Plateau (Figure 2)-this is discussed below. The maximum wave height at Shark Bay was $\sim 56 \mathrm{~cm}$ whilst it was $12 \mathrm{~cm}$ at Geraldton and Fremantle. A slightly higher maximum wave height $(17 \mathrm{~cm}$ ) was predicted at Busselton (Figure 5). 


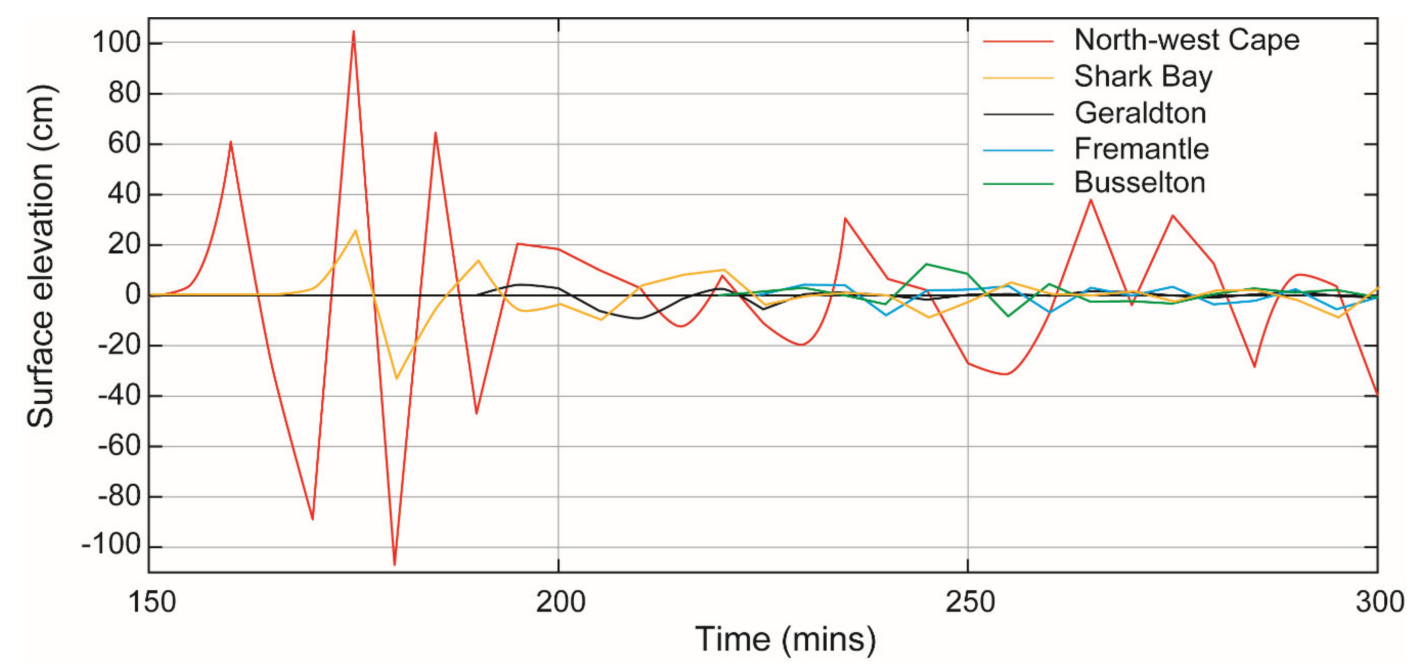

Figure 5. Time series of water levels at the $100 \mathrm{~m}$ contour at North West Cape, Shark Bay, Geraldton, Fremantle and Busselton for tsunamigenic earthquake 4. Locations are given in Figure 2. Time represents elapsed time in minutes since the earthquake.

\subsection{Energy Maps}

The distribution of maximum wave heights ("energy map") for tsunamigenic earthquake scenario one (easternmost location) indicated that the main energy beam impacted the Vening Meinesz seamounts with it moving southward to the west of the Zenith Plateau (Figure 6a). There was an amplification of wave heights at all the plateaus (Exmouth, Zenith, Cuvier and Naturaliste, Figure 2). As the secondary beam was directed to the southeast that interacted with both Exmouth and Cuvier Plateaus that resulted in higher wave heights at North West Cape and Shark Bay (Figure 6b with locations in Figure 2). Scenario two was very similar to 1 except that as the earthquake location was shifted to the east, the main beam interacted directly with Zenith Plateau, increasing the wave heights at the summit (Figure 7a) and along Shark Bay (Figure 7b).
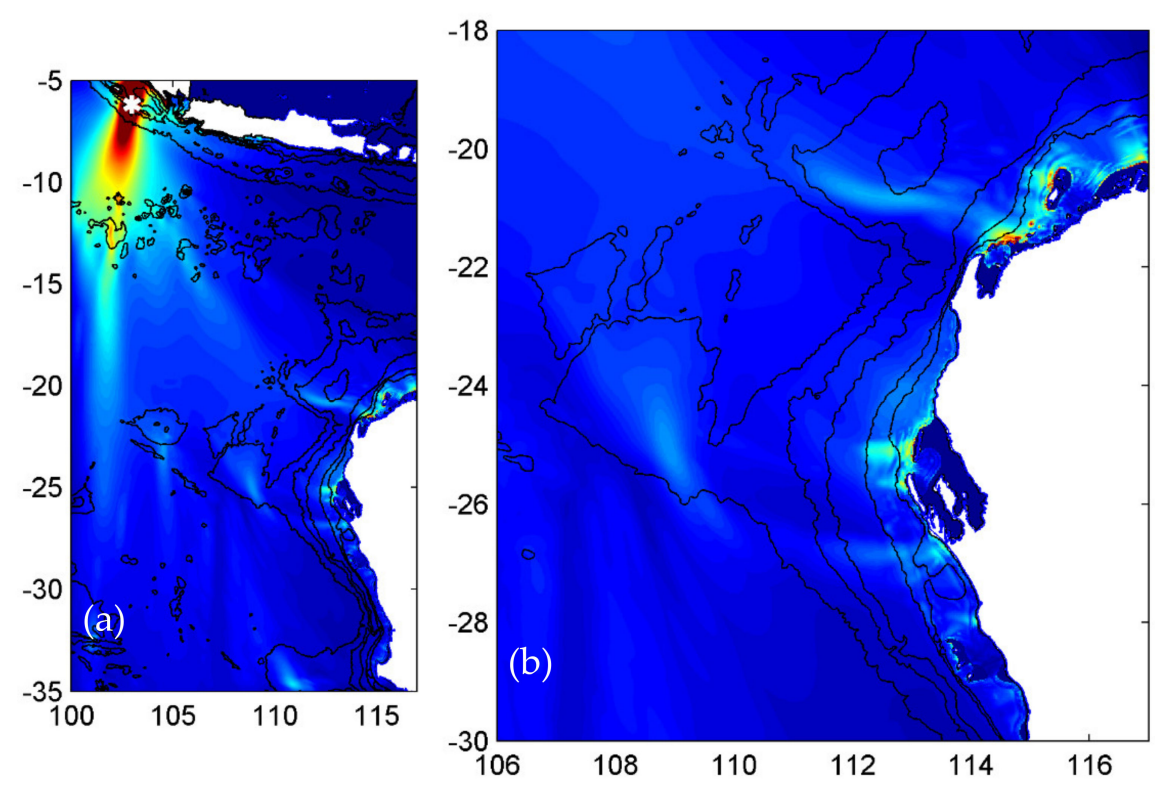

Height (cm)

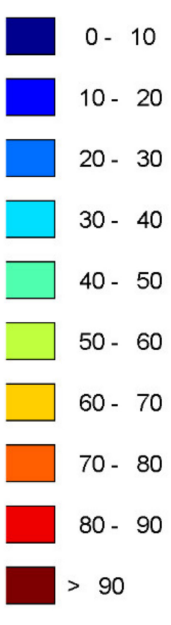

Figure 6. Maximum tsunami wave heights for tsunamigenic earthquake scenario 1. (a) Whole model domain and, (b) a zoomed version around northwest Australia. 

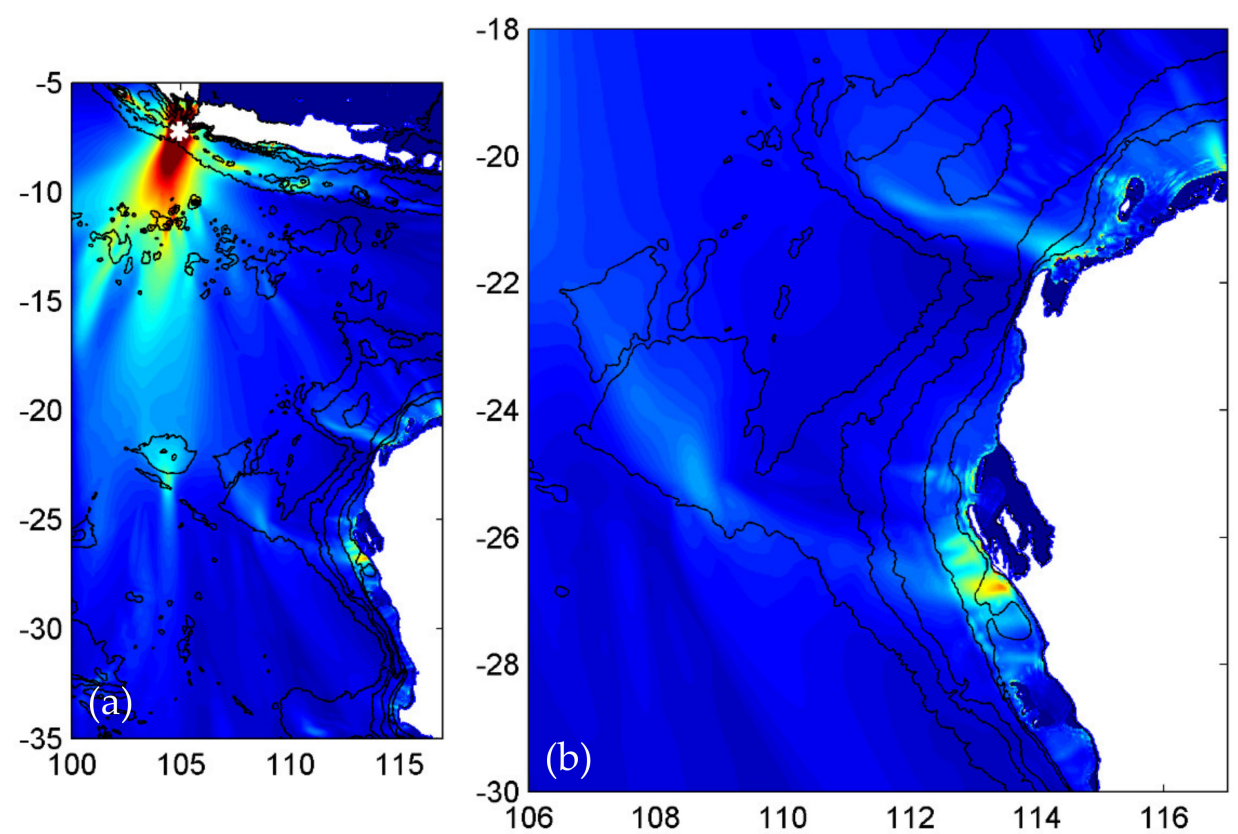

Height (cm)

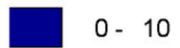

$10-20$

$20-30$

$\square 30-40$

$40-50$

$\square 50-60$

ए $60-70$

$70-80$

$80-90$

$>90$

Figure 7. Maximum tsunami wave heights for tsunamigenic earthquake scenario 2. (a) Whole model domain and, (b) a zoomed version around northwest Australia.

Scenario 3 indicated almost a direct impact on Christmas Island and the tsunami interaction with Vening Meinesz seamounts and Horizon ridge resulted in 4 energy beams (Figure 8a). The western beam exited the domain at $\sim 16^{\circ} \mathrm{S}$. The second beam from the west was directed at Zenith Plateau but the presence of a seamount directly upstream reduced the wave heights at Zenith Plateau compared to scenario 2 (cf. Figures 7a and 8a). The eastern beams interacted with Cuvier and Exmouth Plateaus to create enhanced wave heights at Barrow Island, North West Cape and Shark Bay (Figure 8b).
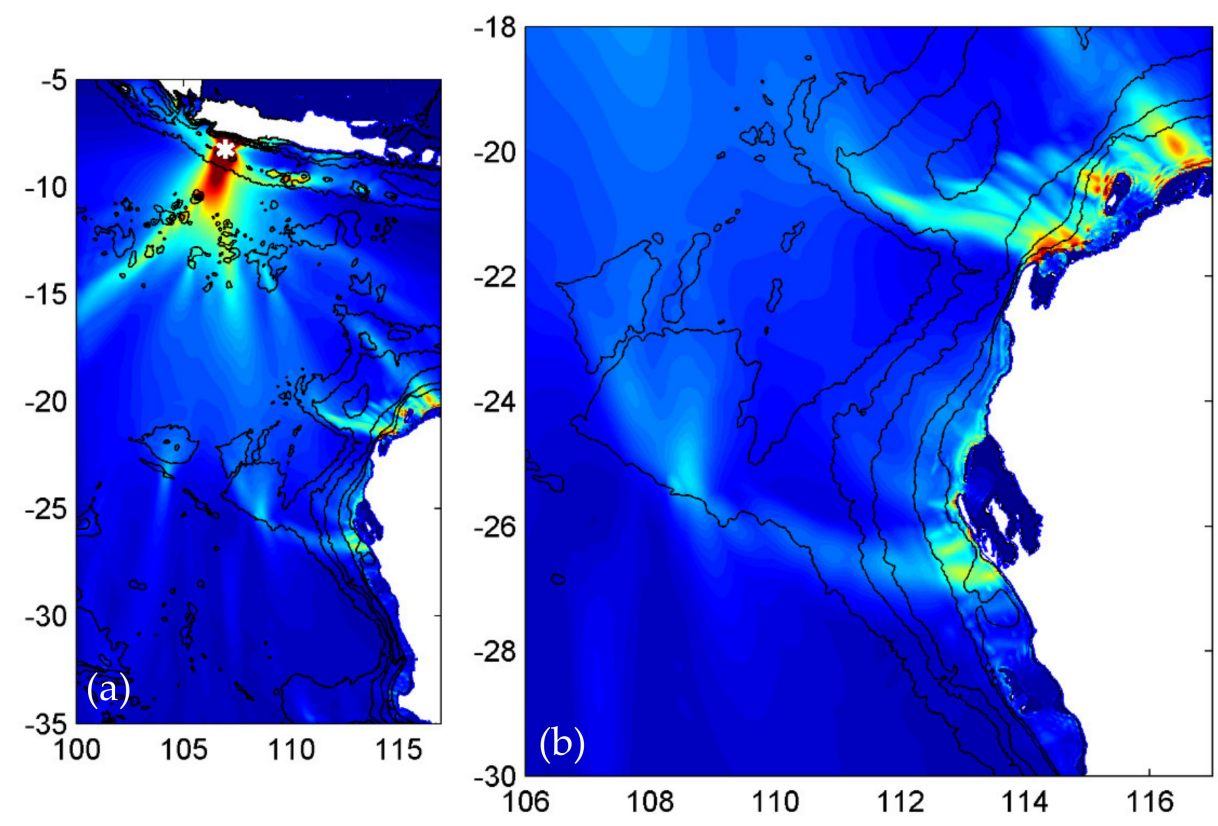

Height (cm)

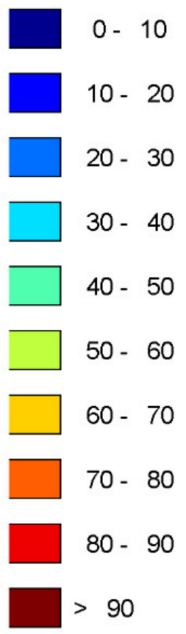

Figure 8. Maximum tsunami wave heights for tsunamigenic earthquake scenario 3. (a) Whole model domain and, (b) a zoomed version around northwest Australia.

Scenario 4 was close to the location of the Pangandaran earthquake (Mw 7.7) and tsunami that occurred on 17 July 2006 [2,10]. There were two major beams (Figure 9a) with the eastern beam 
interacting with Cuvier and Exmouth Plateaus to create increased wave heights at Barrow Island, North West Cape and Shark Bay (Figure 9b), similar to scenario 3. The highest wave heights for the Shark Bay region were predicted from this scenario (see also Section 5 ).
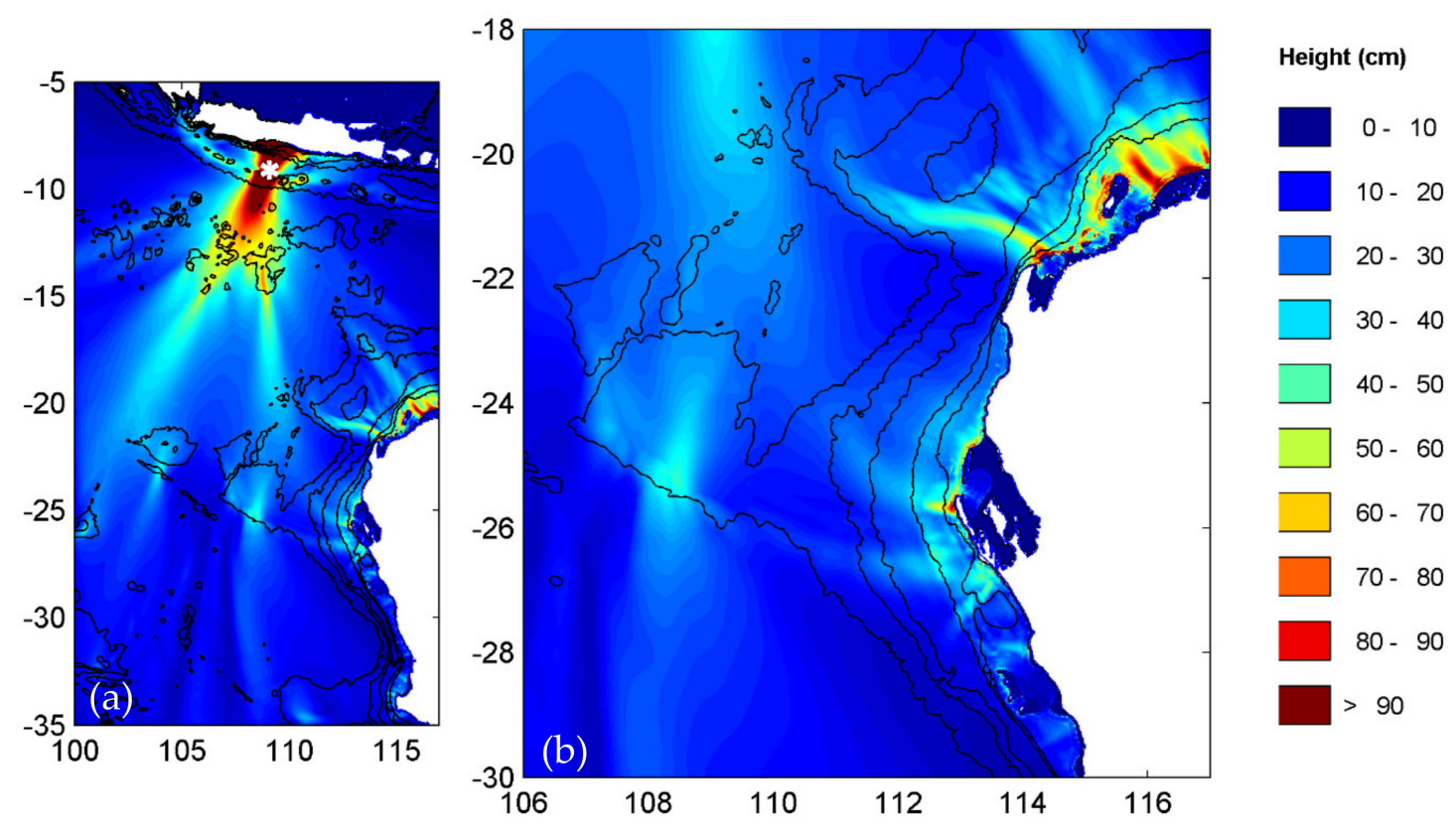

Figure 9. Maximum tsunami wave heights for tsunamigenic earthquake scenario 4. (a) Whole model domain and, (b) a zoomed version around northwest Australia.

Moving to the east, scenario 5 created three energy beams with the two western ones directed to the southwest and away from the landmass (Figure 10a). The eastern beam strongly interacted with Exmouth Gulf, increasing wave heights off Barrow Island (Figure 10b).
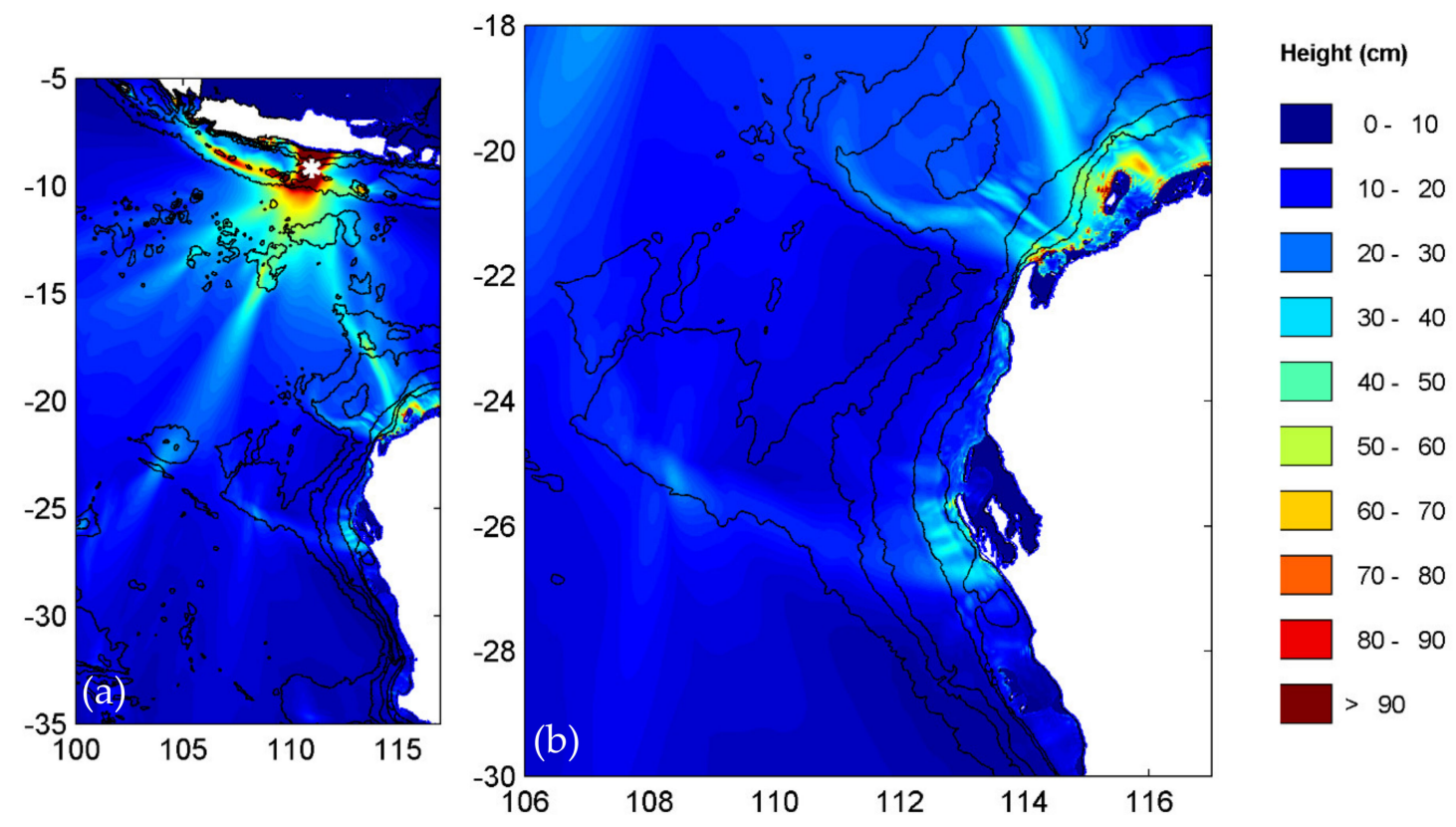

Figure 10. Maximum tsunami wave heights for tsunamigenic earthquake scenario 5. (a) Whole model domain and, (b) a zoomed version around northwest Australia. 
Scenarios 6 and 7 are such that the main energy beams are directed to the southwest (Figures 11a and 12a) away from the landmass. The exception is that the eastern beam that interacts with the Exmouth Plateau and concentrating wave energy at the North West Cape and Barrow Island (Figures $11 \mathrm{~b}$ and 12b).
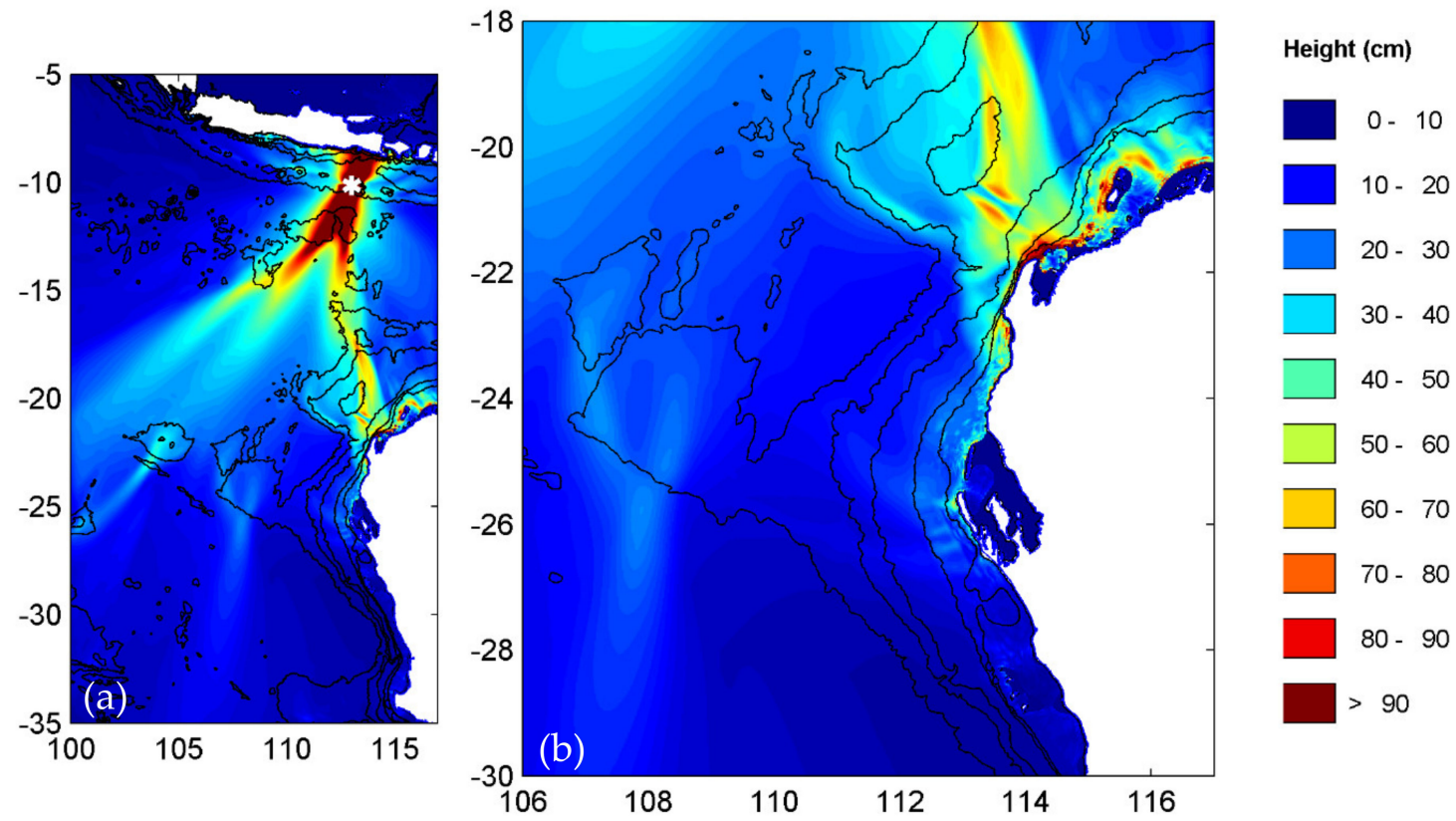

Figure 11. Maximum tsunami wave heights for tsunamigenic earthquake scenario 6. (a) Whole model domain and, (b) a zoomed version around northwest Australia.
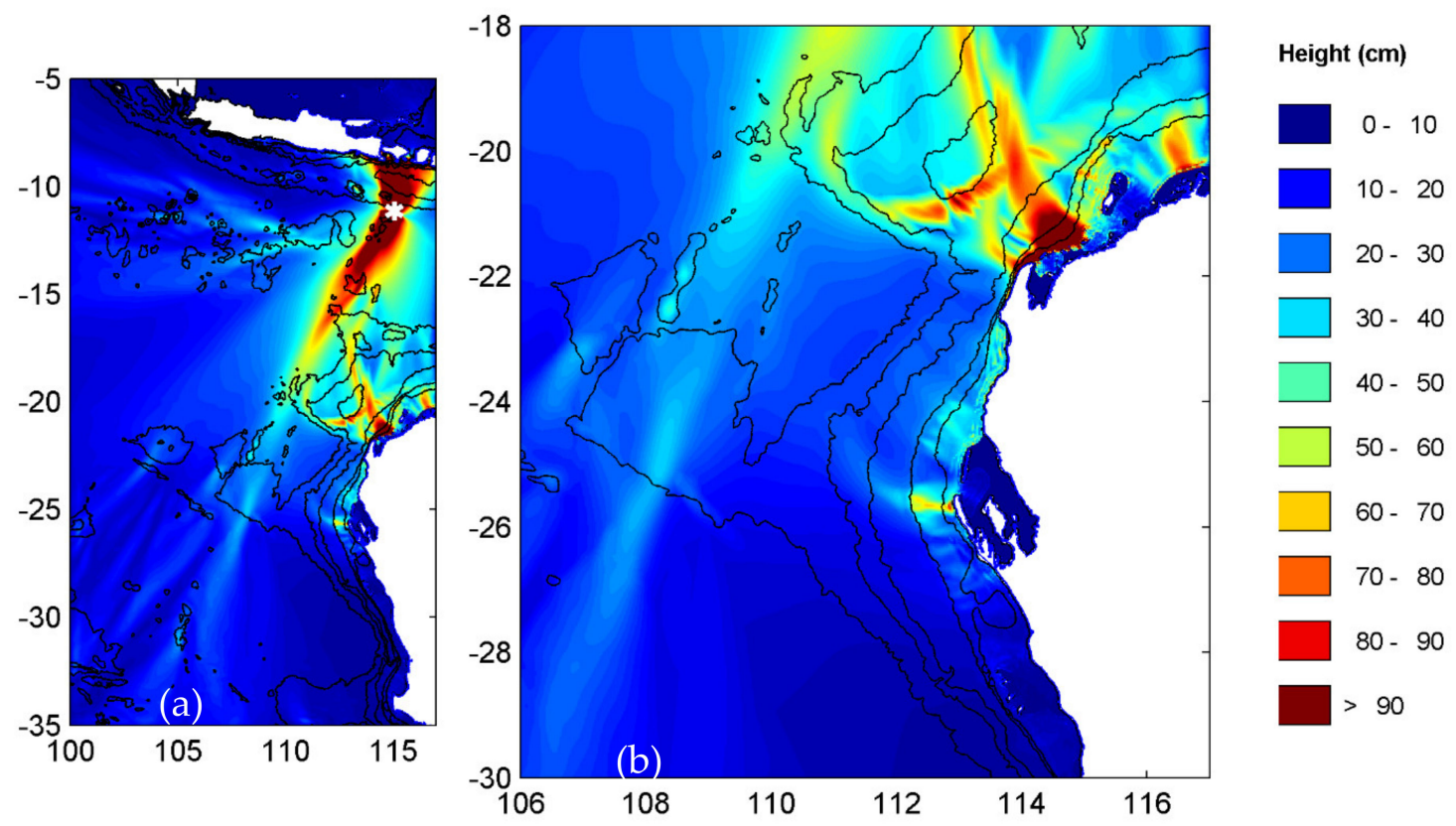

Figure 12. Maximum tsunami wave heights for tsunamigenic earthquake scenario 7. (a) Whole model domain and, (b) a zoomed version around northwest Australia.

The predicted maximum wave heights $\left(\mathrm{H}_{\max }\right)$ along the $100 \mathrm{~m}$ depth contour offshore of North West Cape, Shark Bay, Geraldton, Fremantle and Busselton (see Figure 2 for location) for all the scenarios are summarised in Table 3. In Western Australia, $>90 \%$ of the coastal population is located between Geraldton and Busselton and, therefore, is of interest in terms of tsunami impact. Results 
indicated that there were no significant differences in $\mathrm{H}_{\max }$ at locations south of Geraldton for scenarios one to four $\left(\mathrm{H}_{\max }\right.$ range: 10 to $\left.18 \mathrm{~cm}\right)$ and decreased significantly, $\mathrm{H}_{\max }<10 \mathrm{~cm}$ for scenarios five to seven. This decrease was due to the sheltering effect of the Australian landmass. At Shark Bay, the $\mathrm{H}_{\max }$ varied between 56 and $72 \mathrm{~cm}$ for scenarios one to six but was almost double $(120 \mathrm{~cm})$ for scenario seven. The wave energy map (Figure 12) indicated that the energy was not scattered by the seamounts, as they were located to the west of the energy beam. The tsunami energy was headed directly for Cuvier Plateau and through refraction impacted Shark Bay (Figure 12). Note that due to the Australian landmass there was no direct pathway for the tsunami wave propagation from the earthquake site at scenario seven to Shark Bay (Figure 12). The highest maximum wave heights were predicted at North West Cape for all scenarios and the incident $\mathrm{H}_{\max }$ increased from to west to east. This was mainly due to the distance between earthquake location and North West Cape and the direction of the energy beams that were directed to the south away from North West Cape (Figures 6-8). The North West Cape region has the narrowest continental shelf in the whole region (width $\sim 10 \mathrm{~km}$ ) which also has an influence on the increased the tsunami wave height. The predicted $\mathrm{H}_{\max }$ for North West Cape for scenarios one to three were $<60 \mathrm{~cm}$ but increased by more than four times for scenarios four to seven ( $\mathrm{H}_{\max }$ range: 212 to $264 \mathrm{~cm}$; Table 3 ). The increased wave heights for the easterly scenarios were also due to the effects of the offshore topography, in particular, the Exmouth Plateau (Figure 2). For scenarios four to six, scattered beams from the seamount field directed energy to the Exmouth Plateau that had a convergence effect on North West Cape (Figures 9-11). The highest $\mathrm{H}_{\max }(264 \mathrm{~cm})$ heights were from scenario seven when there were energy pathways from both east and west around Exmouth Plateau (Figure 12).

Table 3. Maximum wave heights recorded along the $100 \mathrm{~m}$ depth contour offshore North West Cape, Shark Bay, Geraldton, Fremantle and Busselton for the seven different scenarios (units are in cm).

\begin{tabular}{cccccccc}
\hline Location & Scenario 1 & Scenario 2 & Scenario 3 & Scenario 4 & Scenario 5 & Scenario 6 & Scenario 7 \\
\hline $\begin{array}{c}\text { North } \\
\text { West Cape }\end{array}$ & 33 & 35 & 56 & 212 & 228 & 240 & 264 \\
\hline Shark Bay & 66 & 64 & 72 & 56 & 58 & 64 & 120 \\
\hline Geraldton & 14 & 16 & 14 & 12 & 6 & 6 & 6 \\
\hline Fremantle & 10 & 12 & 13 & 12 & 8 & 6 & 4 \\
\hline Busselton & 12 & 18 & 17 & 17 & 10 & 8 & 6 \\
\hline
\end{tabular}

\section{Discussion}

Distribution of tsunami energy in time and space is of primary scientific importance and critical for effective tsunami warning and mitigation [25]. In this paper, the role of ocean topography on tsunami propagation was examined through numerical simulation of a series of idealized tsunamigenic earthquakes along the Sunda trench, offshore of the island of Java, Indonesia. Although there have been many earthquakes in the region, only three earthquakes have resulted in tsunamis which have been observed in Australia prior to 2004 (Figure 1). Subsequent to 2004, Western Australia has been impacted by tsunamis on an annual basis with tsunamis occurring in 2004, 2005, 2006 and 2007. However, the maximum tsunami waves have been relatively small along the southwest of Australia [2] and wave heights recorded during seismic tsunami are often exceeded many times annually by meteotsunamis $[3,4]$.

The major tsunami hazard to Western Australia, where a relatively high frequency of tsunami events occur (compared to other parts of Australia), is from tsunamigenic earthquakes along the Sunda Arc [7]. Burbridge et al. [7] indicated that a magnitude nine earthquake offshore of the Indonesian islands of Java or Sumba has the potential to significantly impact a large part of the West Australian coastline. The level of hazard varied along the coast but was highest along the coast from Carnarvon to Dampier and was significantly lower south of Shark Bay. For example, the 1:100 and 1:1000 annual 
recurrence interval (ARI) of maximum tsunami wave heights at Exmouth (close to North West Cape, Figure 2) was 60 and $160 \mathrm{~cm}$, respectively, whilst the same ARI's for Geraldton were 8 and $70 \mathrm{~cm}$ and for Fremantle 4 and $35 \mathrm{~cm}$. The results of this study reveal that the variability in the ARI's value along the coast could be attributed to the offshore topography.

There are a series of bathymetric features along the eastern Indian Ocean between features between the Sunda Arc where tsunamigenic earthquakes occur and southwest Australia that influence tsunami wave propagation and include (Figure 2): Christmas Island, Venin Meinesz Seamounts, Horizon Ridge and several plateaus (Zenith, Cuvier, and Exmouth). The numerical simulations presented in this study have shown that these bathymetric features have a strong influence on tsunami propagation and energy distribution. Initially, the tsunami wave encountered the Venin Meinesz Seamounts (including Christmas Island) and Horizon Ridge that separated the tsunami energy into three to four beams (Figures 8a, 9a, 10a and 11a). Earthquakes that occur at the eastern end (Scenario 7) indicate a single energy beam as the Seamounts and Horizon Ridge do not extend that far (Figure 12). After the tsunami, waves propagated past these features and they encountered the plateaus. These are large topographic features that rise from water depths of 5000 to 2200 m occupying up to $60 \%$ of the water column (Figure 4a) and influence the characteristics of the tsunami through wave shoaling, propagating speed and direction (refraction).

Exmouth Plateau has a large influence on focusing the tsunami waves between North West Cape and Barrow Island with increasing effect for earthquakes to the east. For example, under scenario one (western end), although there was an energy beam moving past the plateau (scattered by the seamounts) maximum wave heights at the $100 \mathrm{~m}$ depth contour was $70 \mathrm{~cm}$ (Figure 6). In contrast, under scenario seven (western end), energy beams were refracted around both sides of the plateau resulting in maximum wave heights at the $100 \mathrm{~m}$ depth contour of $>1.20 \mathrm{~m}$ (Figure 12). Exmouth Plateau acts as a bathymetric feature that focusses tsunami waves at the coast.

Zenith Plateau is located $\sim 1000 \mathrm{~km}$ from the coast and although there is an increase in wave heights on the plateau, downstream effects are limited to the offshore and thus do not have an influence on the coastline (Figures 6-12). In contrast, Cuvier Plateau was impacted from beams scattered by the seamounts, appeared to refract waves towards the coast (Figures 6-9), and was most pronounced for tsunamigenic earthquakes along the eastern region of Java (scenarios 2, 3, 4 and 5). Here, the beams interacted with the plateau and were deflected towards the coast in the Shark Bay region (Figures 6-9). It is interesting to note that the largest tsunami run-up $(7.9 \mathrm{~m})$ recorded in mainland Australia was at Steep Point (Figure 2) resulting from the Mw 7.7 Pangandaran earthquake and tsunami (17 July 2006) [10]. This earthquake was located between scenarios three and four (Figures $8 b$ and $9 b$ ) and simulations highlight the influence of the Cuvier Plateau contributing to the higher run-up heights at this location.

The observed wave heights from many tsunamis to the south of Geraldton have been small [2]. The results from this study indicate that the bathymetric features (seamounts and plateaus) influence the energy distribution through energy scattering and refraction reducing the energy incident in this region. Pattiaratchi and Wijeratne [2], through analysis of sea level data along the WA coast, concluded that the maximum tsunami waves measured in southwest Australia were reflected from the Mascarene Ridge and/or the island of Madagascar. Here, highest waves occurred $15 \mathrm{~h}$ after the arrival of the first wave and the travel path was such that the tsunami waves did not encounter the bathymetric features, as they were directed towards the southwest.

\section{Conclusions}

Numerical simulations of idealised tsunamigenic earthquakes along the Sunda Arc revealed that topographic features in the ocean have a large influence on the distribution of tsunami wave heights, propagating speed and direction. The bathymetric features are located between locations of tsunamigenic earthquakes and the Australian mainland and include Venin Meinesz Seamounts (including Christmas Island) and Horizon Ridge, Exmouth, Zenith and Cuvier plateaus. 
The interaction between tsunami waves and Venin Meinesz Seamounts and Horizon Ridge, located close to the earthquake locations, scatter the tsunami energy into several beams transporting energy in different directions. Exmouth Plateau acts as a focusing feature to increase wave heights between North West Cape and Barrow Island, whilst Cuvier Plateau deflects energy towards Shark Bay. Earthquakes in the eastern section of the Sunda Arc have a larger influence due to the absence of seamounts and Horizon ridge and being close to the source. Although Zenith Plateau has a local effect, it does not influence tsunami waves along the coast. Southwest Australia is "sheltered" from the direct effect of tsunami waves from Sunda Arc due to the combined effects of the Seamounts and Cuvier Plateau in the scattering and refraction of tsunami waves. Cuvier Plateau deflects the wave energy towards the coast.

Funding: The research is funded by the University of Western Australia.

Acknowledgments: The author acknowledges the support of Vasily Titov (PMEL) who provided the source code of the MOST model that was implemented and run at the Pawsey Supercomputer Centre (Perth).

Conflicts of Interest: The author declares no conflict of interest.

\section{References}

1. Pattiaratchi, C.B.; Woo, M. Risk of Tsunami impact at the Port of Dampier. In The University of Western Australia Centre for Water Research Report; No. WP 1520 CP; UWA: Perth, WA, Australia, 2000.

2. Pattiaratchi, C.B.; Wijeratne, E.M.S. Tide gauge observations of the 2004-2007 Indian Ocean tsunamis from Sri Lanka and Western Australia. Pure Appl. Geophys. 2009, 166, 233-258. [CrossRef]

3. Pattiaratchi, C.B.; Wijeratne, E.M.S. Observations of meteorological tsunamis along the south-west Australian coast. Nat. Hazards 2014, 74, 281-303. [CrossRef]

4. Pattiaratchi, C.B.; Wijeratne, E.M.S. Are meteotsunamis an underrated hazard? Philos. Trans. R. Soc. A Math. Phys. Eng. Sci. 2015, A373, 1-23. [CrossRef] [PubMed]

5. Okal, E.A. Seismic parameters controlling far-field tsunami amplitudes: A review. Nat. Hazards 1988, 1, 67-96. [CrossRef]

6. Canterford, R.; Ryan, C.; Crane, G. National Report Submitted by Australia, 2006; Intergovernmental Coordination Group for the Pacific Tsunami Warning and Mitigation System (ICG/PTWS)-XXI; Bureau of Meteorology, Intergovernmental Coordination Group for the Pacific Tsunami Warning and Mitigation System (ICG/PTWS): Melbourne, VIC, Australia, 2006.

7. Burbidge, D.; Cummins, P.R.; Mleczko, R.; Thio, H.K. A Probabilistic Tsunami Hazard Assessment for Western Australia. Pure Appl. Geophys. 2008, 165, 2059-2088. [CrossRef]

8. Dominey-Howes, D. Geological and historical records of tsunami in Australia. Mar. Geol. 2007, 239, 99-123. [CrossRef]

9. Playford, P.E. Recent mega-tsunamis in the Shark Bay, Pilbara, and Kimberley areas of Western Australia. J. R. Soc. West. Aust. 2014, 97, 173-188.

10. Prendergast, A.; Brown, N.J. Far-field impact and coastal sedimentation associated with the 2006 Java tsunami in West Australia. Nat. Hazards 2011, 60, 69-79. [CrossRef]

11. Titov, V.V.; Rabinovich, A.; Mofjeld, H.O.; Thomson, R.E.; González, F.I. The Global Reach of the 26 December 2004 Sumatra Tsunami. Science 2005, 309, 2045-2048. [CrossRef] [PubMed]

12. Pattiaratchi, C.B. The threat of tsunamis in Western Australia. In Proceedings of the Third WA State Coastal Conference, WA Department of Planning, Busselton, WA, Australia, 15-18 November 2005; pp. 210-218.

13. Exxon, N.F. Seabed morphology and offshore resources around Christmas Island, Indian Ocean. In $B M R$ Offshore Sedimentary Basins Program; Geoscience Australia: Canberra, ACT, Australia, 1991.

14. Hoernle, K.; Hauff, F.; Werner, R.; Bogaard, P.V.D.; Gibbons, A.D.; Conrad, S.; Müller, R. Origin of Indian Ocean Seamount Province by shallow recycling of continental lithosphere. Nat. Geosci. 2011, 4, 883-887. [CrossRef]

15. Sayers, J.; Borissova, D.; Ramsay, I.; Symonds, P.A. Geological Frameework of the Wallaby Plateau and Adjacent Areas; Record no. 2002/21; Petroleum \& Marine Division, Geoscience Australia: Canberra, ACT, Australia, 2002.

16. Borissova, I. Seafloor Morphology and Tectonics of the Christmas Island Area, Indian Ocean; Record 1994/2; Australian Geological Survey Organisation: Canberra, ACT, Australia, 1994. 
17. Titov, V.V.; Synolakis, C.E. Modeling of Breaking and Nonbreaking Long-Wave Evolution and Runup Using VTCS-2. J. Waterw. Port Coast. Ocean Eng. 1995, 121, 308-316. [CrossRef]

18. Titov, V.V.; Synolakis, C.E. Extreme inundation flows during the Hokkaido-Nansei-Oki Tsunami. Geophys. Res. Lett. 1997, 24, 1315-1318. [CrossRef]

19. Titov, V.V.; Synolakis, C.E. Numerical Modeling of Tidal Wave Runup. J. Waterw. Port Coast. Ocean Eng. 1998, 124, 157-171. [CrossRef]

20. Titov, V.V.; González, F.; Gonzalez, F.I. Implementation and Testing of the Method of Splitting Tsunami (MOST) Model, 1997; National Technical Information Service, National Oceanic \& Atmospheric Administration (NOAA) Publisher: Seattle, WA, USA, 1997.

21. Titov, V.V. Numerical Modeling of Long Wave Runup. Ph.D. Thesis, University of Southern California, Los Angeles, CA, USA, 1997.

22. Synolakis, C.E.; Bernard, E.N.; Titov, V.V.; Kânoğlu, U.; González, F. Standards, Criteria, and Procedures for NOAA Evaluation of Tsunami Numerical Models; NOAA Special Report, Contribution No 3053, NOAA/OAR/PMEL; NOAA: Seattle, WA, USA, 2007; p. 55.

23. Synolakis, C.E.; Bernard, E.N.; Titov, V.V.; Kânoğlu, U.; Gonzalez, F.I. Validation and Verification of Tsunami Numerical Models. Pure Appl. Geophys. 2008, 165, 2197-2228. [CrossRef]

24. Titov, V.V.; Moore, C.W.; Greenslade, D.J.M.; Pattiaratchi, C.; Badal, R.; Synolakis, C.E.; Kanoglu, U. A New Tool for Inundation Modeling: Community Modeling Interface for Tsunamis (ComMIT). Pure Appl. Geophys. 2011, 168, 2121-2131. [CrossRef]

25. Rabinovich, A.; Candella, R.N.; Thomson, R.E. The open ocean energy decay of three recent trans-Pacific tsunamis. Geophys. Res. Lett. 2013, 40, 3157-3162. [CrossRef]

(C) 2020 by the author. Licensee MDPI, Basel, Switzerland. This article is an open access article distributed under the terms and conditions of the Creative Commons Attribution (CC BY) license (http://creativecommons.org/licenses/by/4.0/). 